\section{öz}

Çalıșmanın amacı, mekanın yaşamla biçimlenen ve insan ile olan sarmal ilişkisinin temelini oluşturan hissedilen özelliklerini anlamaya yönelik bir kuramsal çerçeve ve yaklaşımın geliştirilmesidir. Bunun için öncelikle mekanın yaşamla biçimleniși referans alınarak, mekanın hissedilen özelliklerinin oluştuğu, mekan ile bir araya gelme ilișkilerinin gerçekleștiği ilintiler ve bağlamlar incelenmiştir. Mekanı anlamlandıran ilk ilinti; mekanla ilk karşılaşmanın gerçekleştiği beden ile mekan arasında kurulmaktadır. Bireyin mekanı bedeni ile yaşaması bellekte şiirsel düșünme ile tariflenmektedir. Mekan; yalnızca insanları değil, aynı zamanda şeyleri de barındırır ve onlarla da anlam kazanır. Diğer taraftan, insan topluma bağımlı bir varlık olarak toplumsal yapı içinde mekanı deneyimlemektedir.

Mekanın yaşamsal süreçlerle oluşan hisse-

dilen özellikleri beden, şiir, şey ve toplum ilintileri ile yaşanmakta ve böylelikle anlașılmaktadır. Mekanın hissedilen özelliklerini anlamamızı sağlayan bu ilintiler mekanda bir ağ örüntüsü içinde var olurlar. Bu örüntü, mekanın hissedilen özelliklerini anlamamıza imkan veren bağlam zeminini tanımlamaktadır. Bağlam zemini, ilinti örüntülerini oluşturan birleşenler ve kavramlar sentezlenerek ortaya konmuștur. Böylelikle mekanın hissedilen özelliklerini anlamak için kuramsal çerçeveye ulaşılmıștır. Sonrasında, kuramsal çerçeveye dayanılarak mekanın hissedilen özelliklerini anlamaya yönelik süreç odaklı, rastlantısallıkların, doğrudan ve dolaylı ilișkilerin sürece dahil edilebildiği bir yaklaşım geliştirilmiştir. Bu yaklaşım, mekanın hissedilen özelliklerinin tasarım sürecinde ve mevcut yapılarda sorgulanabilmesine kap1 aralamaktadır. Çalışma bütününde yalnızca sonucun değil, sonuca giden yolun ve bu yolculuk deneyiminin neler söylediğinin de önemsendiği düşünme şekli benimsenmiştir.

\section{Abstract}

The aim of the study is to develop a theoretical framework and approach to understand the sensed characteristics of space which are shaped by life and lay the foundation of its spiral relationship with human. To this end, referring to the formation of space by life, the correlations and context by which space's sensed characteristics are constructed were examined. The first correlation that assigns meaning to space is the body in which the first encounter with the space occurs. An individual living the space in the body is described as poetical thinking in the mind. The space harbors not only humans but also the things and gains meaning along with them. On the other hand, the human as an entity dependent on the society experience the space within the social structure. Space's sensed characteristics which are formed through vital processes are lived through the body, poetic, thing and society correlations and thereby understood. These correlations that enable us to understand the sensed characteristics of space exist within a

I Bu çalısma, Istanbul Kültür Üniversitesi, Fen Bilimleri Enstitüsü'nde Prof. Dr. Doğan Zafer Ertürk Danışmanlığinda tamamlanan Mimari Mekanın Tanımlanması Üzerine Bir Çalışma başlıklı doktora tezi temel alınarak üretilmiştir. süreç odaklı geliştirilen yaklaşım bu makaleye özgüdür.

\title{
Mekanı Anlama Üzerine süreç Odaklı Bir Yaklaşım'
}

Ístanbul Kültür Üniversitesi, Iç Mimarlık ve Çevre Tasarımı Bölümü

Doğan Zafer Ertürk FMV Işık Üniversitesi, İç Mimarlık ve Çevre Tasarımı Bölümü

\section{Giriş}

İnsanların yaşamları çok katmanlılı̆̆ıyla mekanda mekan ile belirmekte ve şekillenmektedir. Aynı zamanda mekan da bu katmanlı süreçler ile var olmakta ve devinimini sürdürmektedir. Mekan ile insan arasinda birbirine sarmalanan ve birbirini bütünleyerek var eden bir ilişkiler ağı bulunmaktadır.

Mekan ile insanın birbirine geçen ilişkisini anlamak ve tanımlamak, insanı konu alan disiplinlerin temel uğraşı olmaktadır. Mekan her disiplin özelinde farklı şekillerde tanımlanmıştır. Mimarlar için kendi özerk alanları olan mekan, çevresel psikolojiciler için psikolojik süreçlerin gerçekleştiği yer, tarihçiler için zamana bağımlı uzam, pragmatistler için ölçülüp biçilerek insan için mükemmel ölçülerde üretilen alan, ekonomistler için üretim tüketim ilişkilerinin düzenlendiği coğrafyadır. Her disiplin, mekanı farklı amaçlarla kullandığ için yaptıkları mekan tanımları -zaman zaman birbirine referans verse bilebirbirinin yerini tutmadığ 1 gibi çoğunlukla birbirine karşıt durmaktadır. "Mekan artık, herhangi bir disipline ait sarsılmaz doğmalara ve ayrıcalıklı metodolojik kalıplara sığdırılamayan disiplinlerötesi bir kavram olarak ele alınmalıdı"” (Aydinl, 2004, s.43).

Disiplinlerarası ve disiplinlerötesi çalışmalar içinde mekanın ne olduğu ve insanın mekanın neresinde olduğu kaybolmaktadır. Diğer yandan insanlar, mekanı sadece kullanmamakta, orada yaşamaktadır. Mekanlar, hem yaşamı hem de yaşanmışlığı barındırarak saklayan gizemleri ile açılip okunmayı bekleyen bir kitap, izlenmeyi bekleyen bir film ve hala keşfedilmeyi bekleyen bir köşe olmaktadır. Mekan bu bağlamı ile bir çok soruyu düşündürmektedir. Neden insan bazı mekanları daha çok sevip anlam ve değer yükleyebiliyor? Ya da nasıl oluyor da bazı mekanlar birbirinden bağımsız çoğu insanda aynı duyguları uyandırabiliyor? Hayaller, düşler, hatırlananlar nasıl mekansallaşıyor? Bir evin odalarına bakıldığında, orada yaşayanların mutlu olduğu anlaşılabilir mi? Ya da insan kendini nasıl oluyor da ilk defa gördüğü bir yere ait hissedebiliyor? Bunlar gibi sorular mekanın değerli bulunan yanları ve hissedilen özellikleri olduğuna işaret etmektedir.

Nalbantlığlu da mimari mekanın bilinemeyen, hala belirsizliğini koruyan bir yanı olduğuyla ilgili şöyle bir tespit yapmaktadır: "Mekana modern bilime özgü Kartezyen ölçütlere uyan kesin bir tanım getirmek gibi beyhude bir çabaya girmek yerine insanla mekan arasındaki ilişkinin gizem yüklü olduğunu daha baştan kabul etmek daha doğru" (Nalbantlioğlu, 2008, s. 100).

$\mathrm{Bu}$ sorular ve tespitlerden yola çıkılarak; çalışmanın konusu, mekan-yaşam biçimle- 
nişinde şekillenen ve insan ile olan sarmal ilişkisinin temelini oluşturan hissedilen özelliklerinin nasıll anlaşılabileceği olarak saptanmıștır. Çalıșmada mekan-yaşam biçimlenmesinde oluşan hissedilen özelliklerin nasıl anlaşılabileceği sorunsal olarak ele alınarak süreç odaklı bir yaklaşım geliştirilmiştir. Süreç odaklı yaklaşımlar, farklı katmanlaşmalar ve ilişkilerin olma, oluş ve oluşum yapıları dikkate alınarak kurgulanmaktadır. Böylelikle tekil katmanların birlikteliği, birlikteliğin oluşum nedenleri tartışmaya açılmaktadır.

\subsection{Anlama: Yaklaşım, Kapsam ve Sinırlılıklar}

Anlam verme bir fikri sorgulamaya yönlendirmektedir. Bu fikre varırken, anlamaya çalıştığımız nesnenin, binanın ya da mekanın değerli mi değersiz mi olduğuna bakmayız. Onun ne hissettirdiğini veya ne düşündürdüğünü anlamaya çalışırız (Botton, 2010). İnam (1992), anlam vermenin, anlamlandırmanın, anlamsız bulmanın -o da bir çeşit anlam verme olduğundan- bulundugumuz ortamı ve çevreyi yaşayabilmemizi sağladığını dile getirmektedir. "İnsanoğlu, mekanı edilgin olarak kabul etmiyor. Ona verileni, değişen gerçeklik olarak ya da ögretilen ortam içinde verilen bir mekan olarak yorumluyor, anlamlandirlyor" (Inam, 1992, s. 182).

Her bir mekanın kendisini diğerlerinden ayıran kendine has özellikleri vardır. Mekanı mekan yapansa onun yaşanmasıdır. Führ'ün de belirttiği gibi mekan, tasarlanınca, üretilince ya da inşa edilince mevcut olmaz. Bir kullanıcı tarafından yaşanarak kabul gördüğünde mekandır ve var olur (Führ, 2008). Bu nedenle de mekanı yaşam ve yaşanmışlık üzerine kurulan ilintiler bütünüyle anlamak gerekmektedir. O'Connor ve McDermott, farklı olgularla beslenen bir süreci anlamak için analitik bakış açısının yerine sentezi önermektedir. Sentez düşüncesi olgu ve sorunların etkileşim içindeki bütününe odaklanmaktadır (O'Connor ve McDermott 1997). Çalışmada da böylesi bir düşünce sistemi benimsenerek mekanın hissedilen özelliklerinin yaşamsal süreçlerde oluştuğu farklı ilintiler sentezlenerek ortaya konmuştur.
Sonrasında mekanda, yaşamla biçimlenen bu ilintilerin mekanla kurdukları bağlam sorgulanmıştır. Sonuçta mekanın hissedilen özelliklerinin anlaşılması için sentez düşüncesinden beslenen süreç odaklı bir yaklaşım geliştirilmiştir.

\section{Mekanı Anlamlandıran İlintiler Bütünü}

Mekan salt bir olgu veya durum değil, farklı ilişkileri, ilgileri ve bağları barındıran ilintiler bütünüdür. Mekanın hissedilen yanını anlamak da bu ilintileri ve ilintilerin mekan ile ilişkisini anlamakla mümkün olacaktır. Mekanı anlamlandıran ilintiler bütünü, mekanın yaşanma süreci referans alınarak oluşturulmuştur. Bu oluşumda mekanın hissettirdikleri bir kurama ya da görüşe dayandırılmak yerine farklı bakış açıları sentezlenmiştir. Sentezlenme süreci karşımıza mekanla farklı bir araya gelme durumlarını açıklayabilecek, mekanla ilinti içine giren beden, şiir, şey ve toplum olgularını çıkarmaktadır. Mekanın hissedilen özellikleri; beden, şiir, şey ve toplum ilintilerinin mekan-yaşam biçimlenişinde bir araya gelişlerinde saklıdır (Şekil 1). Beden mekan ile ilk karşılaşmanın gerçekleştiği yer, şiir mekanın zihinsel oluşumlarının temsili, şey mekanın diğer ögeleri ve toplum da bu yapının toplamı olarak aşağıda daha detaylı ortaya konmaktadır.

\subsection{Bedenin Köprüsü Olarak Mekan}

"Mekan, beden için rahimdir."

Maurice Merleau-Ponty

Mekanın biçimi, ışığı, rengi, dokusu, atmosferi gibi farklı özelliklerinin tümü bedenimizde bir yankı uyandırdığında anlam kazanmaktadır (Merleau-Ponty, 2012). Mekan sınırları, insan bakıșının hareketi ile algisal olarak kavranabilmektedir. Bedenin alg1 ve hareketi mekanın potansiyelini anlamamızı sağlamaktadır.

Mekan içinde beden hem "kendi için varlık", hem de "başkaları için varlık”tır (Sartre, 2003). Kendi için varlık yani özne olan beden, diğerleri için nesne olmaktadır. Diğer bir deyişle algılayan beden, diğer bedenler için algılanan nesneyi ifade network pattern in the space. This pattern defines the context ground facilitating the understanding of space's sensed characteristics. The context ground was elicited by synthesizing the components and concepts that form the correlation patterns. By this means, a theoretical framework was achieved to understand the sensed characteristics of space. Next, based on this theoretical framework, a process-oriented approach was developed to include randomness, direct and indirect relations into the process for understanding the sensed characteristics of space. This approach paves the way for investigating those sensed characteristics during the design process and within the present structures. Such a way of thinking was adopted in the study to attach importance not only to the result but also what this experience has to say.

Anahtar Kelimeler:

Mekanı Anlama, Hissedilen Özellikler, Beden, Şiir, Şey, Toplum

Keywords:

Understanding of the Space, Sensed Characteristics, Body, Poetic, Thing, Society 
Şekil: I

Mekanın Ilintiler Bütünü etmektedir (Sartre, 2003; Perri, 2013). Bu durum algilayan bedenin hem gören hem görünen olma, hem dokunan hem dokunulan olma, aynı zamanda kendini gören ve dokunan olmasından kaynaklanmaktadır (Perri, 2013). Bedenin hem nesne hem özne olması mekanla ilişki kuran araç olabilmesine imkan vermektedir. Diğer bir deyişle, "bedenim olmasayd1, benim için mekan da olmazdı" (Merleau-Ponty, 2005). Bu nedenle algımız tüm eşzamanlığı ile bedenin bütünsel kavrayışı olarak açıklanmaktadır.

Mekanın da içinde yer aldığı nesneler dünyasında beden yaşayan, yani deneyimleyen olarak ele alınmaktadır. Yaşayan beden, deneyimleyen olarak hareketle ilişkilendirilmekte ve hareket eden bedense mekanın homojenliğini kırarak onu yeniden tanımlamaktadır. Beden, mekan ve mekansal ilişki içinde bağlantı noktasını temsil etmektedir. Bu nokta koordinat sisteminde sıfır noktasına karşılık gelerek mekanı düzenlemektedir (Dodd, 2004; Casey, 1997). Bilinçse, beden sayesinde nesneye yönelebilmektedir. Bedenin hareket etmesi, onun üzerinden mekana ulaşması, ya da bir başka deyişle, mekanın çağrısına cevap verebilmesidir (Dodd, 2004; Casey, 1997; Perri, 2013). Mekansa, homojen bir üç boyutluluk yerine, bedenimiz ile ilişki kuran, heterojen bir yayılım olmaktadır (Merleau-Ponty, 2010, p. 26). Böylelikle bedenin her hareketi ile mekan devinim içinde varlığını sürdürmektedir. Bu bağlamda geometrik mekana ya da matematiksel zamana rastlanmamaktadir.

Mekan, beden hareketinin ve algılarının, devamlı ve yeniden gerçekleşmesi ile yaşanmaktadır. Anlamlandırıldığı üzere mekanlar, sadece ölçülen bir uzam değil, bedenin algısı ve hareketi ile yaşanan ve bedenin yaşanmışlık izlerini barındırandır. 


\section{2 Şiirsel Düşünme Olarak Mekan}

"Şiir beklenmedik gerçekliktir."

Peter Zumthor

Mekanın bedenle girdiği ilişki algı ve hareketle anlamı genişleyen katmanlı bir bütünlüktür. Şiirsel düşünme de bu katmanlı yapının bütününün kavranması ve mekanı anlamanın özgün biçimi olma potansiyeli taşımaktadır.

Şiir/şiirsel² (poetic) kelimesi; Grekçe "poesis" kelimesinden gelmekte ve yapma, varlık kazandırmanın yanında, oluşturma, zihinde oluşum gibi anlamları da içermektedir. Aristoteles'in "nous poetikos"una, yani aktif akla referans vermektedir (Berlemont, Goossens, \& Hendrickx, 2014). Yan anlamı "yapmak" olan şiirsellik, salt bir dil biçimi değil, düşünme ve düşündüğünü ifade etmedir. Heidegger, bu temelde şiirin inşa ve iskan etmenin diyalektiğini anlamamızı sağladığını dile getirmektedir. İnşa ve iskan etmek varoluşu anlamlandırma çabalarına içkin olmaktadır, bu nedenle de şiirseldir. Şiir insanı dünyaya ait kılan ve yerleşmesini sağlayan şeydir. Şiirsel yapma faaliyeti olan inşa ve iskan insan varoluşunun köklerini içermektedir. $\mathrm{Bu}$ sebeple, her inşa içinde bir nebze şiir barındırmaktadır (Heidegger, 2001a).

İnsan varoluşunu konumlandıran yapılar insanların ihtiyacına göre inşa edilmekte, sonrasında iskan edilerek yaşanmaktadır. İnşa ve iskan etme birbirinin devamı değil, tamamlayıcısı olarak iç içe geçmektedir. Heidegger, inşanın insanların dünyanın içinde var olma çabasının sonucu olduğunu dile getirmektedir (Heidegger, 2001 v ve Heidegger, 2001b).

Bachelard ise inşa ile mekan arasında kurulan bilinç, hafıza, duyumsama ve hislere dayanan bağları şiirsellik ile açıklamaktadır. Şiirsellik, mekanın, insanın zihninde oluşan farkına vardığı ve varmadığı imgeler bütününe karşılık gelmektedir. Böylelikle mekan soyut ve somut ayrımlarını ortadan kaldıran şiirsel imge ile tanımlanmaktadır. Mekanlar donuk bir şekilde oluşan standartlar toplamı değildir, anılarla yeniden şekillenebilmektedir. Mekanın sürekli oluş halindeki bu poetik temeline de şiir ile erişilebilmektedir (Bachelard, 2013).

Mekan, kelimelerle ifade edilebilecek bir deneyimden çok şiirsel düşünme şeklidir. Şiirsellik kendisinde, anlamları meydana getiren, deneyimle açılanan ve sonu olan varlığının bütününü taşımaktadır (Holl, Pallasmaa, \& Alberto, 1994). Mekanda şiirsellik kavramı bilgi türlerinin zıtlığından doğmaktadır. Yani, gerçek mekanın kaynağı olan standartlar ve sistemlere ait özelleşmiş bilgi ile şiirsel mekanın kaynağı olan insanın bilinçaltındaki bilginin geriliminden kaynaklanmaktadır. İnsan, zihnindeki şiirsel mekan ile gerçek mekanı bağlama çabası içine girmektedir. Şiirsel ve gerçek mekanın çakışması insanın yaşadığ 1 mekanlardan tatmin olmasını sağlamaktadır (Van Schaik, 2002).

Mekanlar, yaşanmış uzamlar olarak şiirsel düşünme ile açıklanabilmekte ve böylelikle mekanın varoluşsal anlamına yaklaşılmaktadır. Yaşanan mekanların her bir noktası farklı şiirsel düşünme veya imge gücüne sahiptir.

\section{3 Şeylerin Yeri Olarak Mekan}

"Avuç içi kadar ufak odamda

Sanki küçük kalbi vurur eşyamda

Elinin dokunmuş olduğu şeyler

Ürperir canlanır sanki ve güler."

\section{Ahmet Muhip Diranas}

Nesne kavramı deneyimden kopuk soyut bir indirgemeyi ifade ettiği için onun yerine şey kavramı önerilmektedir. Nesneler; mekandan, zamandan ve kullanımdan bağımsız tanımlanabilirler. Fakat şeyler mekan ve zaman bütünlüğ̈̈ içinde deneyim ile ilişkilidir (Adams, 2010; Sharr, 2010). Heidegger'e göre şeyler; yeryüzü, gökyüzü, ölümlüler ve tanrılar dörtlüsü içinde bir araya gelerek, varoluşun temel koşullarını ortaya koymaktadır. Yeryüzünde bulunmak zaten göğün altında olmak anlamına gelmektedir. Yer ve gök birlikte tanrısal olanların önünde bulunmakta ve ölümlülerin birbirlerine ait olma durumunu içermektedir. Heidegger bu durumu testi örneği ile açıklamaktadır (Heidegger,
2 Çalışmada poetic teriminin Türkçe karşıllğı olarak, cümle bütünlüğü açısından şiir ve şiirsel kelimeleri birbirinin yerine kullanılmıștir. 
2001c ve Heidegger, 2007). Testi fiziksel biçimiyle ortaya konsa da onu kullanılır yapan içindeki boşluk yani hiçliği olmaktadır. Testi boşluğu saklayarak barındırır; gökler gerekli koşulları sağlar; ölümlü insan susuzluğu için testinin içindekine ihtiyaç duyar ve tanrılara bazen şarap sunarak onurlandırır. Testinin özü bu dörtlünün karş1lıklı etkileşimi ve birlikteliğiyle anlaş1lmaktadır (Sharr, 2010; Heidegger, 2001c).

Heidegger'e göre şeyler, deneyim ve yaşam içinde kullanılan nesnelerin anlamlandırılmasına karșılık gelmektedir. "Bir şey ayırt edici özelliklerini kullanımdan alır; elle tutulunca neye benzediğinden ve insanlarl çevrelerindeki dünyayla nasıl ilişkilendirdiğinden alır. Bir şey insan varlığının parçasıdır, soyut bir alem değil ve insanlar üzerinde düşünmeden önce de zaten hep oradadır" (Sharr, 2010, s. 31).

Şeyler yaşantının içinde bulunmazlar, onlar yaşantı ile birlikte kurulurlar. Burada şey, yönelmiş zihne verilen bilgi içinde, hep aynı kalan, değişmeyen statik bir durum değildir. Şey, mekan içinde yeniden kurulmaya, yani devinimine devam etmektedir (Husserl, 2003). Şeylerin gündelik kullanımı salt ihtiyaç, işlev ve formdan ibaret değildir. Yaşamımız içinde şeyler sınırları, konumları, yönelmeleri ile yakınlık-uzaklık ilişkilerini anlamamıza izin vermektedir (Adams, 2010).

Şeyler salt bir biçim olarak mekanla ilgisinden bağımsız şekilde açıklanamamaktadır (Adams, 2010). Şeyler, yaşamı biçimlendirebilme potansiyeli taşımaktadır. Bu nedenle de şeyler, yaşadığımız mekanları anlamamızı ve anlamlandırmamızı sağlayabilmenin olanaklarını sunmaktadır. “... şeylerin zaman ve mekanda varlı̆̆ını tasarlayamazsinız ama onlarl zaman ve mekana sahip varliklar olarak tasarlamalisinız. Bir şey mekanda basitçe var olmaz ama mekanı kendi içinde geliştirir, bir şey zaman içinde var olmaz, zamanı cisimleștirir" (Führ, 2008).

İnsanlar nesneleri kullanırken onlarda izler bırakır. Bu nedenle anılar şeylere yapışık olarak hatırlanabilmektedir. Anılar, hayaller ve imgeler şeylere yapışmışlardır ve orada bireyi beklemektedir
(Bachelard, 2013). Bu beklemenin yeri bazen hasret duyulan ve hafizada saklanan bir mekan, hatıraların biriktirildiği ilk ev, bazen çocukluk anılarının toplandığ 1 oyun evi olan masanın altı, bazen geçmiş zamanı saklayan müzeler olmaktadır. Bu kapsamda, mekanın hissedilen özellikleri şey ilintisi ile anlaşılabilmektedir.

\subsection{Toplumsal Yapı Olarak Mekan}

"Mekanlar toplumları, toplumlar da mekanlarl şekillendirir.'

Anthony Giddens

Salt mekan yoktur, farklı türde mekansal ilişkiler ve mekansallaşmalar bulunmaktadır. Bu mekansal olgular da toplumsal nesneler üzerinden kurulmaktadır. Mekan, içinde bulunduğu toplumsal olgulardan ayrı mutlak bir geometri olarak görülemeyeceği gibi, mekansal olguları da tümüyle yok sayip topluma indirgemek yetersiz bir çaba olmaktadır (Urry, 2010). Mekanı bütün olarak kavrayabilmek için toplum ile olan ilintilerinin anlaşılması önemli görülmektedir.

Toplumsal olgular bireyin gündelik yaşamı içinde sıradan olarak gördüğ ü deneyimlerine dayanmaktadır. Sosyal bilimlerin bahsettiği şeyler zaten çevremizde ya da bizzat kendi hayatımızda olağan şeyler olarak yer almaktadır. Bu noktada bireysel olandaki toplumsal olan1, tikel olandaki genel olanı anlamak önemli görülmektedir (Bauman, 2005). Mekan da böyle bir yaklaşımla üretilir. Mekan hem bireyselliğin sığınağıdır, hem de toplumsal yaşama içkindir. İnsan toplumsal bir varlık olarak, içinde bulunduğu toplumsal çevre içinde mekanı yaşamaktadır.

Giddens da toplum veya toplumsal olguların insan eylemleri içinde yaratılmakta ve yeniden üretilmekte olduğunu ifade etmektedir. İnsan eylemleri toplumsal kuramlar içinde neden-sonuç ilișkileri ile değil, bütüncül ilintilerle var olmaktadır. Toplumsal olan ancak mekan ve zaman bütünlüğünde hem bireysel hem toplumsal olarak tekrarlandığ 1 ölçüde şekillenmektedir. Mekan, içinde yer alan nesneler ile algılanırken sırf mekansal gerçekliğiyle değil, toplumsal gerçekliğiyle birlikte kavranmaktadır (Giddens, 2011). 
Toplumsal yapı inşa eden tuğlaların, en küçük birimin bireyden sonra aile yapısı, diğer bir deyişle hane halkı olduğu düşünülmektedir. Toplumun en küçük birimi olarak kabul edilen aile, organizmanın en küçük birimi gibi çalışmaktadır. Ailede yaşanan en küçük değişim, doğrudan organizmayı, yani toplumu etkilemektedir (Gür, 2000). Mekanı bütüncül anlamak için, içinde bulunan toplumu ve onu var eden hane halkı yapılanmasını ve değişimini de anlamak gerekmektedir.

Toplum yapısı aynı zamanda mekanı tanımlayan kültürel faktörleri içermektedir. Kültürel faktörler; toplumsal yapı içinde mekanın biçimlenişini ve mekanla kurulan bağ1 şekillendirmektedir (Bauman, 2005; Gür, 2000). Böylelikle beden deneyiminde, hangi içsel güdülerin neden belirgin ve baskın olduğu açığa çıkmaktadır. Toplum insana kültür çevresi, yani kültürel bir mekan inşa etmektedir. Sonuçta, birey ve aile, zaman-mekan bütünlüğü içinde daha önceden eylem ve düşünceler ile oluşmuş kültürel kodlar taşımakta, toplumsal yapıyı oluşturmaktadır.

\section{Mekanı Anlamlandıran Bağlamların Oluşumu}

Mekanın hissedilen özelliklerini anlamamızı sağlayan yukarıdaki ilintiler mekanda bir ağ örüntüsü içinde var olurlar. Bu örüntü mekanın hissedilen özelliklerini anlamamıza imkan veren bağlam zeminini tanımlamaktadır. "Bağlam; bağımlı olmak, doğru ya da yanlış hiçbir ölçütün bulunmaması anlamına değil, ölçütlerin her bağlam için yeniden belirlenmesi anlamına gelmektedir" (Serim ve Ünlü, 2007). Bu kapsamda, ilintilerin mekanda, mekanla ve birbirleriyle olan bağlamı sorgulanarak, mekanın hissedilen özellikleri bütüncül olarak anlaşılacaktır.

Mekanın hissedilen özelliklerinin ilk bağlamı, mekanla ilk karşılaşmanın gerçekleştiği ve mekan ile insan ilişkisinin temeli olan bedendir. Mekan başlı başına bir dünya, beden ise o dünyayı tanımlayandır. Mekanla bedenin bu ilinti örüntüsü; alg1, hareket ve deneyim aracılığıyla şekillenmektedir. Algidan harekete uzanan oluşum; beden algısı, duyu ve duyumsama ile kurulmaktadır. Bedenin mekandaki yayılım hareketiyse, algı ile birleşerek deneyimi tanımlamaktadır. Alg1, hareket ve deneyim arasında kuvvetli bir birliktelik bulunmaktadır. Bu birliktelik; beden algısı, duyu, duyumsama ve yayılım ile şekillenmektedir. Böylelikle mekanın hissedilen özelliklerinin, yaşamla birlikte şekillenen beden bağlamı oluşmaktadır.

Bireyin mimari mekanı bedeni ile yaşaması bellekte şiirsel şekilde, diğer bir deyişle şiirle tariflenmektedir. Yaşanan mekanların her bir noktası farklı şiirsel durumlar yaratma gücüne sahiptir. Şiirin bu potansiyeli, mekanın hissedilen özelliklerini ifade edebilmesine imkan vermektedir. Bu süreç; mekanın şiirsel şekilde düşünülmesi, düşlenmesi ve imgelenmesinde saklanmakta ve bu üçlünün ilinti örüntüsü, bilinç, bilinçdışı, düş kurma ve hayal üzerinden gerçekleşmektedir. Şiirsel düşünme, düşleme ve imge; bilinç, bilinçdışı, hayal ve düş kurmanın yansımaları olmaktadır. Mekanın hissedilen yanını şiirsel açıdan anlamlandıran bu katmanlı örüntü, şiirle kavranabilmektedir.

Mekan yalnızca insanları değil, aynı zamanda şeyleri de barındırmaktadır. Mekan şeyin varoluşuna izin verenken, birey şeyin varoluşunu tamamlayan olarak kavranabilir. Mekanda şey ilintisi; özne ve nesneyi, ikilik tanımlayan iki ayrı olgu olarak değil, birliktelik içinde ele alır. Bu ikilik ve birlik döngüsel bir yapı içindedir. Çünkü mekanın içindeki bir beden, diğer nesnelere göre özne konumundayken başka bir beden için şey konumundadır. Böylelikle özne ve nesnenin birbirine yapışık bir ilișki içinde olduğu anlaşılmaktadır. Ayrıca özne ve nesnenin birbirlerine göre bu durumları ve anılar ile birbirlerine temasları devingenlik göstermektedir. Sonuçta; mekanda, şey bağlamı ile oluşan hissedilen özellikler gün yüzüne çıkmaktadır.

Toplumsal yapıdaki her değişiklik, içinde veya dışında bulunduğu mekanla bir bütündür. Mekan ile toplumun bu bağlamı; aile, toplumsal yapı ve kültür zemininde oluşmaktadır. Bu oluşumda; toplumsal 
Şekil: 2

Mekanı Anlamlandıran Bă̆lamlar

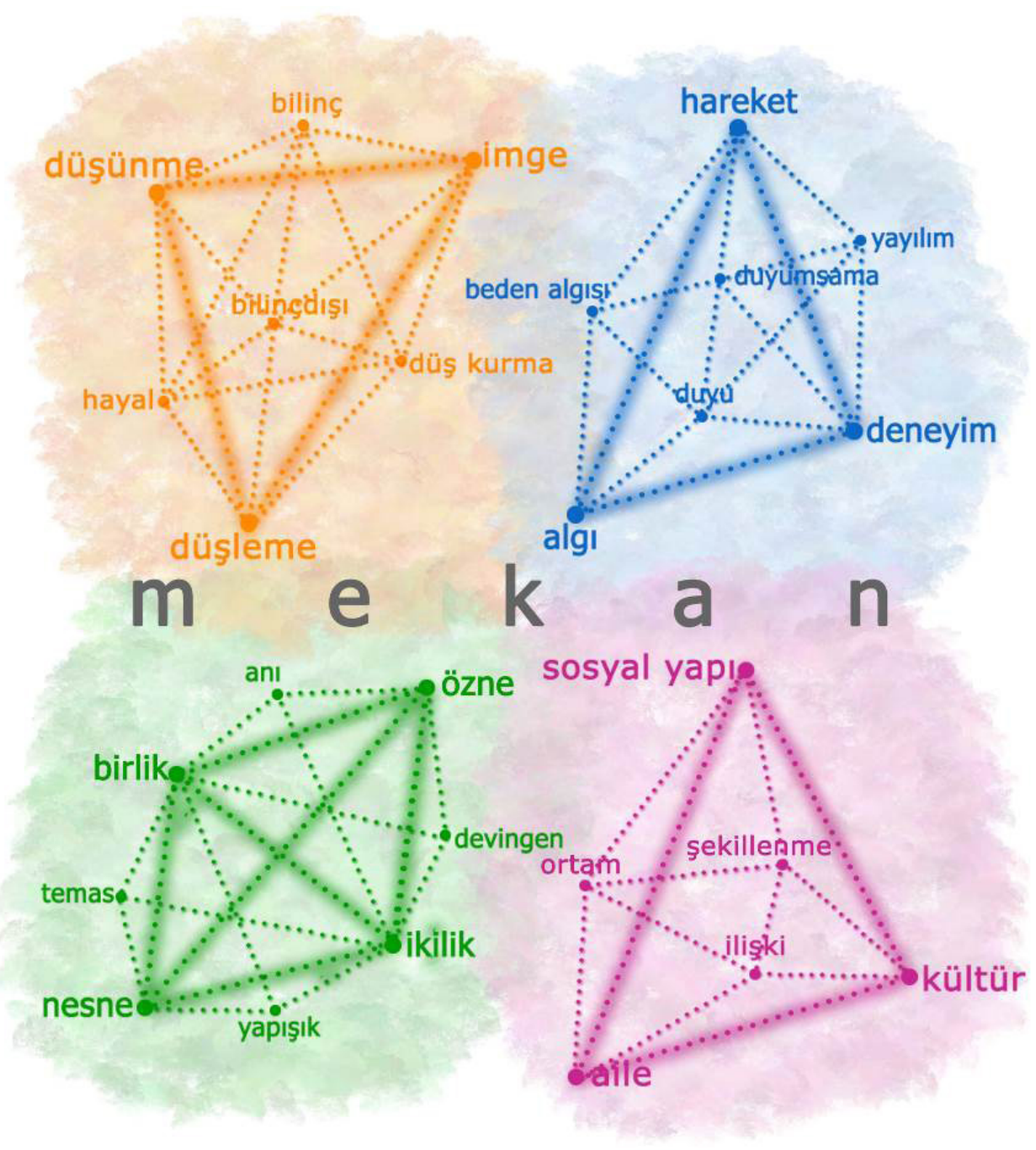

yap1 ve aile, bulundukları ortamın birer parçası olarak toplumu etkilemektedir. Diğer yandan; aile, kültür ve sosyal yapıdaki birbirini tamamlayan ilişkiler ve şekillenmeler ile toplumsal yapı biçimlenmektedir. Sonuçta, mekanın hissedilen özellikleri açısından mekan ile toplum bağlamı anlaşılmaktadır. Bu anlamlanma ise şekillenmeler, ilişkiler ve ortam ile sağlanmaktadır. Böylelikle, mekanda toplum bağlamı kurulmakta ve mekanın hissedilen özelliklerine yaklaşılmaktadır.

Beden, şiir, şey ve toplum mekanın hissedilen özelliklerini anlamamıza imkan veren ilintiler örüntüsü içinde mekanın bağlam zeminini ifade etmektedir (Şekil 2). Bu bağlamların birbirleriyle kesişimleri, mekan-yaşam biçimlenişinde şekillen- mekte ve mekanın hissedilen özelliklerini oluşturmaktadır. Böylelikle ilintilerin mekanda yaşamla birlikte şekillenen ilinti örüntüsüne dayalı bağlamı Şekil 2'deki gibi olmaktadır. Mekanın hissedilen özelliklerinin anlaşılmasını sağlayan ilintilerin, mekan-yaşam biçimlenişinde, bağlamını oluşturan ağ örüntüsü ortaya konmuştur. Böylelikle hem mekanın hissettirdiklerinin hem de tasarlanacak mekanın hissedilen yanının sorgulanabileceği düşünme şekli oluşturulmuştur.

\section{Sonuç Yerine: Yaklaşım ve Öneriler}

Mekanı anlamlandıran ilintilerin bağlamı, mekan-yaşam biçimlenişinde şekillenmekte ve geçirdikleri süreçler mekanın hissedilen özelliklerini ortaya koymak- 

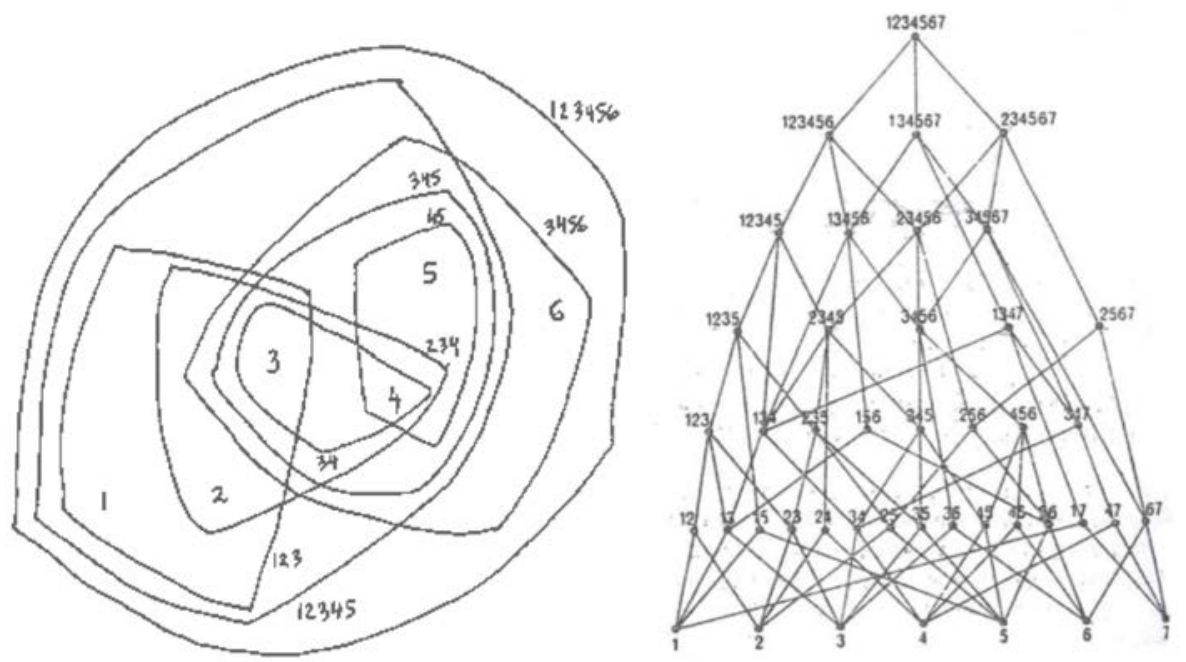

tadır. Bu bağlam yapısı ile çalışmanın literatür üzerinde temellenen kuramsal çerçevesi çizilmiştir. İlintilerin bağlamları karmaşı k bir zemin ifade etmektedir. Karmaşık zeminin anlaşılması, "bütün, parçaların toplamından fazladır" ilkesinden yola çıkılarak, tekli olarak anlamlandırılan bağlamların, kesişimlerinin ve birlikteliklerinin sorgulanması ile sağlanabilecektir. Bu sorgulama için önerilen yaklaşım, Alexander'ın farklı birleşenlerin etkileşim içinde bulunarak daha büyük ve karmaşık sistemler oluşturmasını gösteren yarı kafes düşünme şeklinden yola çık1larak geliştirilmiştir. Yarı kafes düşüncesinde her bir birim birbiriyle bağıntılıdır; ayrıca bu bağıntıların oluşturduğu alt kümeler de hem birbirleriyle hem de diğer birimlerle ilişki içindedir (Alexander, $1970 \mathrm{ve}$ Karatani, 2014) (Sekil 3).

Alexander yarı kafes düşünme şeklini kendiliğinden oluşan şehirlerin yaşam kurgusunu ve modern kentlerin bu oluşumdan yoksunluklarını açıklamak için kullanmaktadır. Modern kentlerin yarı kafes sistemiyle ele alındıklarında, gündelik ilişkilere de cevap vereceğini dile getirmektedir. Kentsel birimler olarak ele aldığ yapıların ve yapı gruplarının alt kümeler olarak birbiriyle raslantısallıklara izin veren bağlantılarını açıklamaktadır (Alexander, 1970 ve Karatani, 2014). Ancak bu çalışma mekanın hissedilen özelliklerine odaklanmaktadır. Hissedilen özellikler anlaşılacak ise bu düşünme şekline "oluş"un okunabileceği süreç de dahil edilmelidir. Bunun için, her bir kesişim ele alındığı gibi, kesişimler oluşurken kendiliğinden gelişen ve katmanlaşan süreç de incelenmelidir (Şekil 4).

Mekanın hissedilen özelliklerinin anlaşılması için Şekil 4'te de görüldüğü gibi kesişimler lineer bir akış içinde değil, üst üste gelmeler ile ortaya konmalıdır. Mekan yaşam biçimlenişinde her bir ilinti kendi bağlamı içinde diğer ilintiler ile farklı kesişimler oluşturmaktadır. Her bir ilintinin oluşturduğu kesişimler katmanlaşarak bütünü tamamlamaktadır. Böylelikle her bir ilinti hem kendi bağlamı içinde hem de diğer ilintilerle birlikteliği doğrultusunda ele alınabilmektedir. Bu da ilintilerin ve bağlamları oluşturulan kavramların farklı oluşumlar içinde sentezlenmesine izin vermektedir. Her oluşum sürecinde bağlamlar kendi sınırlarını tanımlayabilmektedir. Diğer yandan bu yaklaşım, kesişimler meydana gelirken süreçte kendiliğinden gelişen ilişkiler ve katmanlaşmalar da ortaya koymaktadır. Çalışmanın bütününde ortaya konan ilintiler, bağlamlar arası ilişkiler ve bu ilişkilerin kurulma sürecindeki katmanlaşmalar da yaklaşıma dahil edilmiştir.
Sekil: 3

Yarı Kafes Düşünme Diyagramı

(Alexander, 1970) 
Sekil: 4

Mekanı Anlama Üzerine Geliştirilen süreç Odaklı Yaklaşım

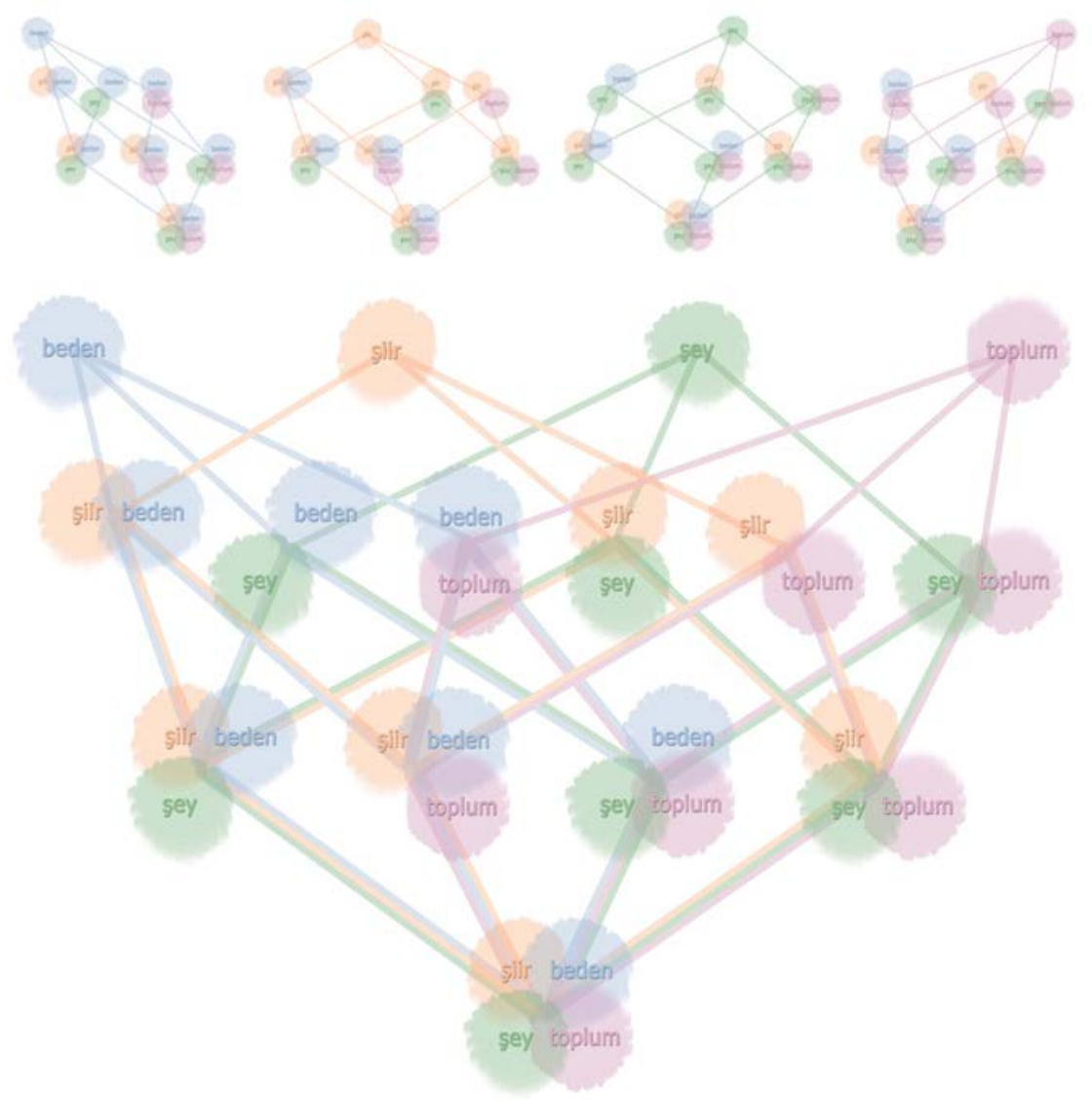

Mekan tasarımında ve mevcut mekanlarda hissedilen özellikler aranacaksa, bu arama önerilen yaklaşım ile gerçekleştirilebilir. Yaklaşımın sunduğu kuramsal çerçeve üzerinden bağlamların kesişimleri hem sorgulanmak istenen başlangıç, hem de bulunma $(m a)$ sı aranan sonuç olarak ele alınabilir. Böylelikle başlangıç ve sonucun birbiri içinde eriyerek ve dönüşerek geliştiği süreç odaklı tasarım ve araştırmalar yapılabilir. Süreç odağıysa mekan-yaşam biçimlenişinde şekillenen hissedilen özelliklerin anlaşılmasına ve tasarıma dahil edilmesine imkan verir.

Mekanın hissedilen özelliklerinin anlaşılması için geliştirilen yaklaşım aynı zamanda aşağıdaki konuları ve önerileri gündeme getirmiştir.

- Mekanın hissedilen özelliklerinin anlaşılması için geliştirilen yaklaşım; tasarım araştırmalarında sonucun nasıl ele alınabileceğini de sorgulamaktadır. Araştırma sonucun ne söylediğiyle birlikte, araştırma bütününden sonuca giden yolculuğun ne söylediğini de önemsemektedir. Yaklaşımın dayandığı düşünme şekli, çevremizi saran mekanların sadece bir ürün olarak değil, yaşayan bir organizma gibi ele alındığ araştırmalara kapı aralamaktadır.

- Her geçen gün hizla değişen ve gelişen mimarlık alanında, mekana dair çalışmaları psikolojik, sosyolojik, fizyolojik gibi temel olgulara dayandırmak yerine, yeni kuramsal yapıların yolları aranmaktadır. Çalışmada da mekanın hissedilen özellikleriyle ilgili farklı düşüncelerin sentezlenmesiyle oluşturulan, gelişime açık bir kuramsal çerçeve çizilmiştir. Çalışmanın bütünü, mimarlığın temel konusu olan mekan bilgi üretimine hem kuramsal açı- 
dan, hem de geliştirilen yaklaşımla düşünme sistemi açısından katkı sağlamaktadır.

- Çalışmada sunulan kuramsal çerçevenin farklı düşünme sistemleri üzerinden yeniden sorunlaştırılması yaklaşımın çeşitlenmesine firsat verecektir. Örneğin, Deleuze ve Guattari tarafından geliştirilen kök-sap ilişki şemaları bulunmaktadır. Kök-sap fikrine dayandırılan bu sistem sürekli yıkılarak yeniden kurulabilmekte, böylelikle ana ve ara öğeler birbirine dönüşebilmektedir. Bu durum bir kökü kesseniz bile sapların yeni kökü oluşturabilmesine benzetilerek açıklanmaktadır (Ballantyne, 2010). Diğer yandan gelişen dijital araçlar ve küreselleşen toplumsal ilişkiler, mekan kavrayışlarını çeşitlendirmiştir. Hensel ve diğ. (2009) heterojen mekan kavramı üzerinden çeşitlenen mekan kavrayışlarını tartışmaya açmaktadır. Modern ve postmodern mekan söylemlerinin günümüzde dijital araçlar ve küreselleşen toplumsal ilişkilerle karmaşıklaşan mekânsal durumları ifade etmekte yetersiz kaldığını dile getirir. Çözümün tek bir mekan söylemi kurulmasıyla değil, farklı mekânsal ilişkilerin sorgulanmasıyla aranması gerektiğini ifade eder. Bunun için de çeşitlenen mekânsal oluşumları kabul ederek katmanlaşmaya açık taktik ve stratejiler önerir (Hensel, Hight, \& Menges, 2009).

- Mekan tasarımı eğitimine, bu kuramsal çerçevenin ve yaklaşımın nasıl dahil edileceği ve eğitim felsefesi açsından konunun tartışılması önemli görülmektedir. Sunulan kuramsal çerçeve, mekanın hissedilen özelliklerinin eğitime dahil edilmesine, tasarım eğitimi için yeni yaklaşımların geliştirilmesi ve bunların farklı düşünce sistemleri ile ortaya konmasina imkan vermektedir. Diğer yandan, geliştirilen yaklaşımın farklı yapı tipolojilerinde araştırılması ve elde edilen bulgu- ların birbiriyle bağlarının sorgulanması konuyu farklı boyutlara taşıyabilir.

Mekanın hissedilen özelliklerini anlama çabasındaki çalışmada, farklı düşüncelerin sentezlendiği kuramsal çerçeve ve bu çerçeveye dayanan bir yaklaşım geliştirilmiştir. Yalnızca sonucun değil, sonuca giden yolun ve bu yolculuk deneyiminin neler söylediğinin önemsendiği düşünme şekli benimsenmiştir. Önerilen kuramsal çerçeve ve yaklaşım yeni çalışmalar için örnek; çıkan sonuçlarsa yeni çalışmalar açısından başlangıç niteliği taşımaktadır• 


\section{Kaynakça}

Adams, C. A., 2010. Teachers Building Dwelling Thinking with Slideware. Indo-Pacific Journal of Phenomenology, 10 (1): 1-12.

Alexander, C., 1970. Sehir Ağaç Değildir. Mimarlık Dergisi, 75: 56-64.

Aydınlı, S., 2004. Epistemolojik Açıdan Mekan Yorumu. içinde Mimarlık ve Felsefe. İstanbul: YEM Yayınları.

Ballantyne, A., 2010. Mimarlar için Deleuze ve Guattari, çev. Öğdül, R., İstanbul: YEM Yayınları.

Bachelard, G., 2013. Mekanın Poetikası. çev. Alp Tümertekin, İstanbul: Kesit Yayıncılık.

Bauman, Z., 2005. Thinking Sociologically. Malden: Blackwell.

Berlemont, T., Goossens, W. \& Hendrickx, A., 2014. The Sense of Architectural Constructs in Research. Helsinki, http://designresearch.aalto.fi/events/ aor2014/papers/Berlemont.pdf.

Botton, A. D., 2010. Mutluluğun Mimarisi. cev. Tellioğlu Altuğ, B., İstanbul: Sel Yayıncılık.

Casey, E., 1997. The Fate of Place: A Philosophical History. Berkeley: University of California Press.

Dodd, J., 2004. Crisis and Reflection: An Essay on Husserl's Crisis of the European Sciences. New York: Kluwer Academic Publishers.

Führ, E., 2008. Mimarlığın Mevcudiyeti. Zaman-Mekan, 40-57. İstanbul: YEM Yayınlar1.

Giddens, A., 2011. Sosyoloji - Kisa Fakat Elestirel Bir Giriş, çev. Battal, Y.Ü., Ankara: Siyasal Kitabevi.

Gür, Ș. Ö., 2000. Doğu Karadeniz Örneğinde Konut Kültürü. İstanbul: YEM Yayınlar1.

Heidegger, M., 2001a. ...Poetically man dwells..., içinde Poetry, Language, Thought, çev. Hofstadter, A. New York: Harper \& Row, s. 209-227.

Heidegger, M., 2001b. Building Dwelling Thinking. Poetry Language, Thought, cev. Hofstadter, A., 141-159. New York: Harper \& Row.

Heidegger, M., 2001c. The Thing. Poetry, Language, Thought, çev. Hofstadter, A., 161-180. New York: Harper \& Row.

Heidegger, M., 2007. Being and Time. çev. John Macquarrie ve Edward Robinson. Oxford: Blackwell.

Hensel, M., Hight, C. ve Menges, A., 2009. En route: Towards a Discourse on Heterogeneous Space beyond Modernist Space-Time and Post-modernist Social Geography. Space Reader: Heterogeneous Space in Architecture, ed. Hensel, M., Hight, C. ve Menges, A., 9-37. London: John Wiley \& Sons.

Holl, S., Pallasmaa, J. \& Alberto, P.-G., 2006. Questions of Perception, Phenomenology of Architecture. California: William Stout.

Husserl, E., 2003. Fenomenoloji Üzerine Bes Ders. çev. Tepe, H., Ankara: Bilgesu Yayıncılık.

İnam, A., 1992. Yaşanacak Bir Mekan Tasarlamak. Araştırma Ankara Üniversitesi Dil ve TarihCoğrafya Fakültesi Felsefe Bölümü Dergisi 14: 1177-188.

Karatani, K., 2014. Metafor Olarak Mimari. cev. Yildırım, B., İstanbul: Metis Yayınları.

Merleau-Ponty, M., 2005. Phenomenology of Perception. London and New York: Taylor and Francis e-Library.

Merleau-Ponty, M., 2010. Algılanan Dünya. İstanbul: Metis Yayınlar1.

Merleau-Ponty, M., 2012. Göz ve Tin. İstanbul: Metis Yayınlar1.
Nalbantlığlu, H. Ü., 2008. Nedir Mekan Dedikleri. Zaman-Mekan, 88-105. İstanbul: YEM Yayınları.

O'Connor, J. \& McDermott, I., 1997. The Art of Systems Thinking: Essential Skills for Creativity and Problem Solving. England: Thorsons

Perri, T., 2013. Image and Ontology in Merleau-Ponty. Continental Philosophy Review, 46 (1): 75-97.

Sartre, J. P., 2003. Being and Nothingness: An Essay on Phenomenological Ontology. London: Routledge.

Serim, S. \& Ünlü, A., 2007. Yapılı Çevre Üzerinden Mimarlık Bilgisinin Üretilmesi: Elestirel Bir Değerlendirme. ITÜ dergisi/a, 6 (2): 25-36.

Sharr, A., 2010. Mimarlar İçin Heidegger. İstanbul: YEM Yayınlar1.

Urry, J., 1999. Mekanları Tüketmek. İstanbul: Ayrıntı Yayınlar1.

Van Schaik, L., 2002. Poetics in Architecture. Chichester: Wiley. 